\title{
フッ化物を含むアルミナ系触媒による $n$-ヘキサンの接触分解
}

(昭 和 39 年 11 月 11 日 受 理)

\author{
三宅 坦*・生越久靖*・勝田匡俊**・高 橋 英二*
}

\begin{abstract}
nーヘキサンの接触分解反応における各種固体酸の反応初期活性を微量接触反応装置によって比較検討した結果，フッ化 物を含むアルミナ系触媒が市肘のシリカ・アルミナ触媒扰よび未処理のフルミナ触媒よりす高い活性を有していることを 見い出した。また流通法によって未処理のアルミナに比較すると脱水素能は低下し，触媒表面上の炭素状堆積物の生成が 抑制されている。

ホウフッ化水素酸，5７\%（重量)，フッ化水素酸，5７\%，フッ化水素フンモニウム，2４％（いずれも計算値）を それぞれ含むアルミナ触媒が最も高い活性を示した。

末処理のアルミナ触媒のフッ化物による活性化はアルミナの比較的弱いルイス酸が強いブレンステッド酸型活性中心に 転化したためと推察され，さらに表面積当りの酸性度の增加もその一因と考えられる。
\end{abstract}

\section{1 粕言}

本来工業的にシリカ・アルミナ触媒扣よびシリカ・マグネシア 触媒によって炭化水素を接触分解し,ガソリンを製造しているが その他シリカ・チタニア系, 燐酸・アルミナ系触媒が知られてい る。石油工業に扔㤝る接触分解では高オクタン価ガソリン製造が 主目的であって，その時にプロピレン，ブチレンなどが副生成物 として得られる。アルミナ触媒をハライドによって活性化したも のはアルキル化, 異性化, 重合反応などに用いられるが1), 分解 反応に応用された例はほとんど見られない。

軽質炭化水素を原料として接触分解によって選択的にプロピレ ン,ブチレンを製造するための触媒を微量接触反応装置でスクリ ーン試験を行なった結果から、フッ化物を含むアルミナ触媒が優 れていることを確かめた。

フッ化物を含むアルミナ触媒がカルボニウムイオンを含む反応 を非常に促進することは，Rijnders ${ }^{2)}$ および $\mathrm{Holm}^{3)}$ によって報 告されているが，その活性化される過程に関して未だ不明な点も 多いので, 酸性度を中心に検討した。

\section{2 実 験 方 法}

\section{$2 \cdot 1$ 実験装置}

$2 \cdot 1 \cdot 1$ 微量接触反応装置(ハルス法 $)^{4,5,6)}$ 因 1 に示すよ5に, ガスクロマトグラフ（島津 GC-1 B 型）の分離カラムの前に反応 管を接続したものである。反応管はバイコール製の内径 $3 \mathrm{~mm}$ の

* Hiroshi MIYAKE, Hisanobu OgOSHI, Eiji TAKAHASHI 丸善石油株式会社中央研究所：和歌山県海草郡下津町

** Masatoshi KATSUTA 同上, 現在東京工業大学高分子工 学科 : 東京都目黒区大岡山

1) A. S. Russel, "Alumina Properties", Tech. Paper 10, p. 24 ; Aluminum Co., of America, Pittsburgh:(1953).

2) G. W. A. Rijnders, G.C.A. Schuit, "Cationic Polymerization and Related Complex" p. 133 ; Edited by P. H. Plesch, Cambridge; W. Heffer \& Sons Ltd. (1953).

3) V.C. F. Holm, A. Clark, American Chemical Society Atlantic City, N. J., Sept., 1962, Preprints, Division of Petroleum Chemistry 7 No. 4 p. A-45.

4) S. A.Green, J. Am. Chem. Soc. 62, 55 (1958)

5) P. H. Hammett, ibid. 77, 5860 (1955), 79, 2091(1957).

6) D. W. Bassett, H. W. Habgood, J. Phys. Chem. 64, 769 (1960).
U字管で $6 \mathrm{~mm} \phi \times 20 \mathrm{~mm}$ の触媒だめがあり，一定量の触媒をこ こに充填して, 空部を 14〜32 メッシュの磁製のラシッヒで満し， 熱電対を触媒層の外壁に密着させ，加熱を均一なものとするため に,アルミナ粉末の流動バス中に浸した。原料は微量注射器でせ ラムキャップから一定量 $(5 \mu l)$ をパルスとして注入し，キャリ ヤーガス（ヘリウム）と同伴して触媒層で反応させ，反応混合物 はそのまま分離カラムに送って分析する。反応温度は $450 \sim 500^{\circ} \mathrm{C}$ で, 反応圧力は $0.2 \mathrm{~kg} / \mathrm{cm}^{2}$ (指示圧) である。

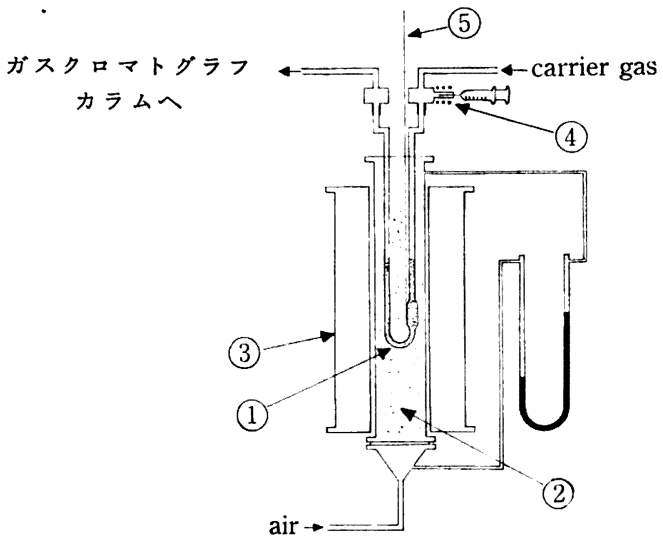

因 1 微量接触反応装置

(1)：反応管，(2): 流動バス，(3): 電気石，(1):セラムキ+ ブおよびヒーター, (5)：慜電対

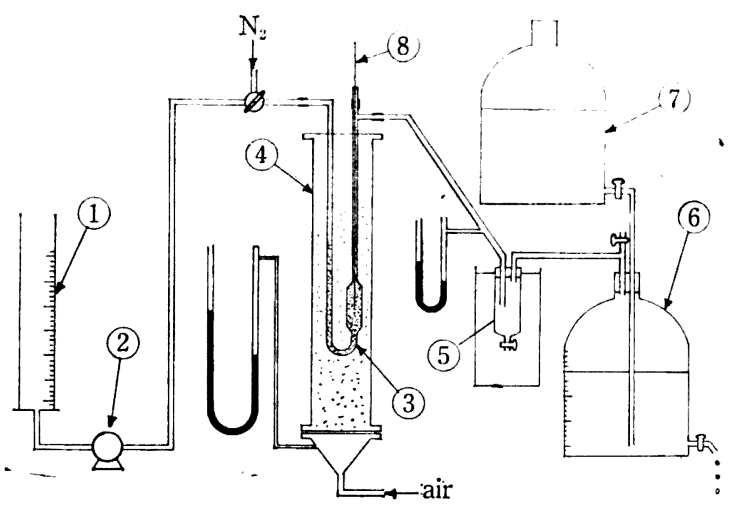

因2 流通式反応装置

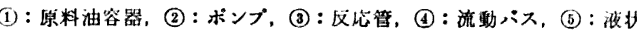

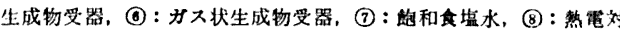


2・1・2 流通式反応装置 パルス法の結果を扣ぎない, 展開する ために用いた固定床流通反応装置を図 2 に示す。反応管は $2 \cdot 1 \cdot 1$ と同様にバイコール製の U 字管で $20 \mathrm{~mm} \phi \times 60 \mathrm{~mm}$ の触媒だめ があり，熱電対の検出端は触媒層中央部に挿入している。原料は ミルトンロイポンプで一定流速で送入し，生成ガス拉よび夜状生 成物を各々計量する。

\section{$2 \cdot 2$ 触 媒}

実験に供した触媒は次の通りである。おのおの略号で示し, 調 製法の概略和よび製造会社名を記す。

$S ：$ 住友化学株式会社製活性アルミナ

$\mathrm{SF}$ ：ベースを S として，これをフッ化水素酸の水溶液中で含浸 させ, 湯浴上 $80^{\circ} \mathrm{C}$ で水分を追い出し, 電気炉中で $500^{\circ} \mathrm{C}$ に保ち 焼成した。

$\mathrm{SBF}$ : ベース S をホウフッ化水素酸の水溶液中に含浸させ, SF と同様に処理した。

$\mathrm{ABF}$ : 特級硝酸アルミニウムの $1 \mathrm{~N}$ 水溶液を強くかきまぜな がら $2 \mathrm{~N}$ のアンモニア水を滴加し，規定の $\mathrm{pH}$ 值で中止する。 得られたアルミナゲルを 1 昼夜放置した後，口別し，十分洗浄寸 る。ゲルの含水量をあらかじめ求めて执いて，ポリェチレン製の 容器中に移し, ホウフッ化水素酸を含む水溶液を加え, 湯浴上に て水分を蒸発させる。さらに固化したゲルを減圧下で 6 時間， $160^{\circ} \mathrm{C}$ で乾燥し, 電気炉中 5 時間, $500^{\circ} \mathrm{C}$ で焼成した。

$\mathrm{DABF}$ : 上記 $\mathrm{ABF}$ と同様な方法で調製したアルミナゲルを蒸 発乾固し, 砕いて粒度を統一したものを, ホウフッ化水素酸を含 む水溶液中に浸し，湯浴上で水分を蒸発させ，電気炉中 $500^{\circ} \mathrm{C} て ゙$ 焼成した。

$\mathrm{OBF}:$ アルミニウムイソプロポキサイドをイソプロピルアルコ 一ル水混合液中で加水分解して，アルミナゲルを調製した。ABF と同様均質混合法にてホウフッ化水素酸を加えた。

DOBF : ゲル調製法は OBF と同様で，ホウフッ化水素酸は $\mathrm{DABF}$ と同様に含浸法によって加えた。

SAD : 市販シリカ・アルミナ触媒 (W.R. Grace \& Co.) アル ミナの含有率は $25 \%$ (重量) である。

\section{$2 \cdot 3$ 原 料}

n-ヘキサンはフィリップス社製の research grade のものでガ スクロマトグラフでは不純物は認められなかった。

\section{$2 \cdot 4$ 分析法}

$2 \cdot 4 \cdot 1$ 生成物分析 パルス法に执いては迅速な分析をするた めにオレフィン，パラフィンの分離をせず，同一炭素数毎に一つ のピークとした。カラムはスクワラン $25 \%$ クロモソープを使用 し，ヘリウムをキャリヤーガスとして，流速 $40 \mathrm{ml} / \mathrm{min} て ゙$ て流し た。流通法で得たガス生成物は質量分析計（日立製作所）により， 液状生成物は F.I.A 法で組成分析を行なった。

2.4.2 フッ素およびホウ素の分析 ホウ素7) ; 試料 $0.5 \mathrm{~g}$ を鉄 製のルッボにとりカセイソーダで溶融し，溶融物を水にとかした 後, 鉄その他の沈殿物を口別し，口液はさらにH型陽イオン交換 樹脂を通して,ナトリウム,アルミニウムなどの陽イオンを除く。 流出液を的 $10 \mathrm{~m} l$ まで濃縮し，これを $50 \mathrm{~m} l$ のメスフラスコに 入れ, $\mathrm{pH}=7$ の緩衝溶液 $2.5 \mathrm{ml}$, EDTA $2.0 \mathrm{ml}$ 㧊よびカーミ ン試薬溶液 $5.0 \mathrm{ml}$ を加え, 希勫後その吸光度を $554 \mathrm{~m} \mu$ で測定

7) 日和, 分析化学 12,703 (1963).
する。あらかじめ作製してある検量線からホウ素含有量を求める。 フッ素 ${ }^{8)}$; 試料 $0.5 \mathrm{~g}$ を蒸留フラスコに入れ, 水 $50 \mathrm{ml}, 1 \mathrm{~N}$ 硫酸水銀溶液 $50 \mathrm{ml}$ を加え, ガラス球を入れフッ素をケイフッ化 水素酸として水蒸気蒸留をする。留出液の一部をメスフラスコに とり，ジルコニウムアリザリン試薬を加えて希䣋し，1 昼夜放置 し, その吸光度を測定し, あらかじめ作成した検量線からフッ素 の定量を行なった。

\section{$2 \cdot 5$ 酸性度の測定}

2.5・1 Benesi 法 $\left.{ }^{9}, 10\right)$ ハメット ${ }^{11)}$ の指示薬を用い, ベンゼン 溶液中に触媒を懸濁させ， $n$-ブチルアミンで滴定して，酸性度の 測定を行なった。ベンゼンは完全に脱水し, 各指示薬は再結晶法 により精製した。用いた指示薬の酸性色と塩基性色扣よび $\mathrm{p} K_{\mathrm{a}}$ 值を表 1 に示す。

表 1 酸強度測定に用いたハメットの指示薬

\begin{tabular}{|c|c|c|c|}
\hline 示 & 塩基性色 & 酸性色 & $\mathrm{p} K_{\mathrm{a}}$ \\
\hline フェニルアヴナフチルアミン & 黄 & 赤 & +4.0 \\
\hline p-ジメチルアミノアジベンゼン & 黄 & 赤 & +3.3 \\
\hline ヘンンゼンアゾジフェニルアミン & 黄 & 紫 & +1.5 \\
\hline ジシンナマルアセトン & 黄 & 赤 & -3.0 \\
\hline ベンザルアセトフェノン & 船 & 黄 & -5.6 \\
\hline アントラキノン & 無 & 黄 & -8.2 \\
\hline
\end{tabular}

2.5.2 プロトン交換法 ${ }^{12)}$ 酢酸アンモニウムを用い，触媒表 面上のプロトンを交換させ，遊離した酢酸を測定した。

\section{$2 \cdot 6 \mathrm{X}$ 線回折}

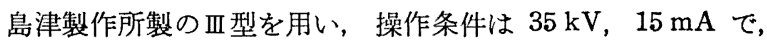
$\mathrm{Cu}-K_{\infty}$ 線を使用した。

\section{3 結果}

\section{$3 \cdot 1$ X 線回折}

$\mathrm{X}$ 線回折の結果を図 3 に示す。市肘アルミナ触媒 S の調製法は 不明であるが，X線回折から葟燥前のもの（A）は $\alpha$-basic

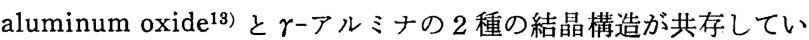
るように思われる。さらに $500^{\circ} \mathrm{C} て ゙ 4$ 時間空気を流しながら焼成

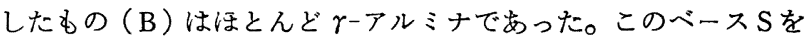
ホウフッ化水素酸水溶液中に浸漬して調製した SBF-6 11 は (C) のよ5に $2 \theta=38.5^{\circ}$ の所に回折線が認められず, 全体としてピ 一クの尖鋭度が減少している。合成触媒 ABF-6 (D) も SBF-6 と同様な回折線を示した。 $\mathrm{SBF}-6$ 扣よび $\mathrm{ABF}-6$ 共に $\boldsymbol{\gamma}$-アルミ ナの構造を保持しているものと考えられる。

\section{$3 \cdot 2$ フッ化物の影響}

市販アルミナSをべースとして，各種のフッ化物を含浸法によ って添加した場合，それぞれの n一へキサンの分解活性に执よぼ す影響は表 2 に示す通りである。

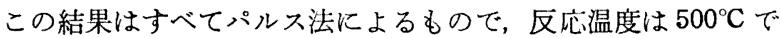

8) 不破, 分析化学 3, 98 (1954).

9) H. A. Benesi, J. Am. Chem. Soc. 78, 5490 (1956).

10) H. A. Benesi, J. Phys. Chem. 61, 971 (1957).

11) L. P. Hammett, A. J. Deyrup, J. Am. Chem. Soc. 54, 2721 (1932)

12) V.C. F. Holm, G. C. Bailey, A.Clark, J. Phys. Chem. 63, 129 (1959).

13) A.S.T.M. Data による.

※1 SBF-6 は2·2 で述べたよ5 SBF で表わされる触媒の 略号で 6 はフッ素（計算值）を6\%（重量）含む。 


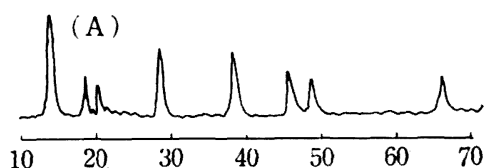

(B)

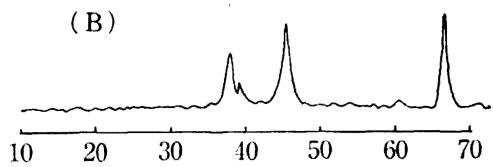

(c)

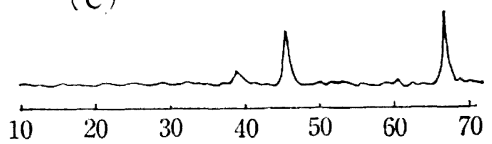

( D )

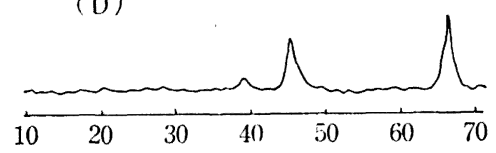

困 3 触媒の X 線回折

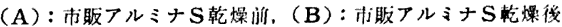

(C) : SBF-6, (D) : ABF-6

表 2 各種フッ化物の効果

\begin{tabular}{|c|c|c|c|c|}
\hline 添 加フ フ 化物 & $\begin{array}{c}\text { 表面债 } \\
\mathrm{m}^{2} / \mathbf{g}\end{array}$ & $\mathrm{p} K_{\mathrm{a}} \leqq 4.0$ & $\mathrm{p} K_{\mathrm{a}} \leqq-3.0$ & 反度率 \\
\hline な & 526 & 0.46 & 0.19 & 10.0 \\
\hline HF フッ化水素酸 & 275 & 0.60 & 0.42 & 65.0 \\
\hline $\mathrm{HBF}_{4}$ ホウフッ化水素酸 & 362 & 0.52 & 0.47 & 55.0 \\
\hline $\mathrm{NH}_{4} \mathrm{HF}_{2}$ フッ化水素アンモニウム & 207 & 0.35 & 0.29 & 49.5 \\
\hline $\mathrm{NH}_{4} \mathrm{~F}$ フッ化アンモニウム & 175 & 0.40 & 0.12 & 4. 3 \\
\hline $\mathrm{NH}_{4} \mathrm{BF}_{4}$ ホウフッ化アンモニウム & 227 & 0.55 & 0.47 & 31.2 \\
\hline
\end{tabular}

ある。触媒の初期活性はフッ化アンモニウムを除いていずれもべ ースアルミナSょりも高く, さらに反応温度 $570^{\circ} \mathrm{C}$ に打ける市販 シリカ・アルミナ SAD の反応率は $12 \%$ ，シリカ・マグネシア で3\%であるから，フッ化物を含むアルミナ触媒の分解に対する 初期活性はかなり高いものといえるだろう。酸性度の分布からも わかるよ5に, 酸強度の強い酸量の多いことは分解活性に対する 必要条件だと考えられる。

\section{3 フッ化物による活性化}

図 4 はベースSにフッ化水素酸, ホウフッ化水素酸, フッ化水 素アンモニウムを含浸法によって加えた触媒のフッ素含有量（計

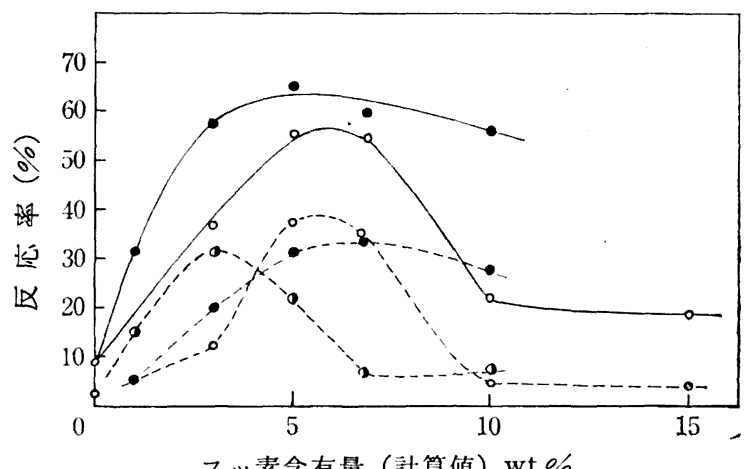

フッ素含有量（計算値）wt \%

図 4 フッ化物含有量と活性

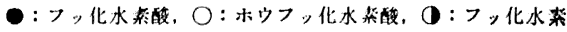
フンモニウム，炎線 $500{ }^{\circ} \mathrm{C}$, 点線 $475^{\circ} \mathrm{C}$
值）と $n$-ヘキサンの分解活性を示す。フッ化水素酸，および ホウフッ化水素酸の場合，ともに 5 7 wt \%で最大活性を示す。

Holm らはフッ化水素酸処理を施こしたアルミナ触媒によるnオクタンの接触分解, オルトキシレンの異性化, プロピレンの重 合において，フッ素の量が增加すると活性が增加するが，数 \% 以上になると活性は增加しなくなると述べている。フッ化水素ア ンモニウムの場合は含有量が $3 \%$ 近くで最大を示している。

流通法による結果を表 3 に示す。 SBF および ABF 触媒は市販 のシリカ・アルミナ触媒よりも高い分解活性を有しているが，ガ スげのオレフィン/パラフィンの值は低く, 液状生成物の F.I·A 法による分析では芳香族，オレフィンの含有量が多い。アルミナ のみでは，ガス中の水素含有量が多く脱水素能も非常に強いが， $\mathrm{ABF}, \mathrm{SBF}, \mathrm{OBF}$ 系のようにフッ化物を含むアルミナ触媒では脱 水素能が低下していることが注目される。

表 3 流通法に上る分解反応

\begin{tabular}{|c|c|c|c|c|c|c|c|}
\hline \multirow[b]{2}{*}{ 触 } & \multirow{2}{*}{$\begin{array}{c}\text { 他盢度 } \\
(\mathrm{C})\end{array}$} & \multirow{2}{*}{$\begin{array}{l}\text { ガス中の } \\
\text { オレフィ } \\
\text { ンハバラ } \\
\text { フィン }\end{array}$} & \multirow{2}{*}{$\begin{array}{c}\text { 反応率 } \\
(\%)\end{array}$} & \multicolumn{3}{|c|}{ 沎状生战物朝成 } & \multirow{2}{*}{$\begin{array}{r}\mathrm{H}_{2} / \text { ガX } \\
\times 100\end{array}$} \\
\hline & & & & $\begin{array}{l}\text { バラフ } \\
\text { イン }\end{array}$ & $\begin{array}{l}\text { オレフ } \\
\text { イン }\end{array}$ & 乲香故 & \\
\hline$S A D$ & $\begin{array}{l}570 \\
600\end{array}$ & $\begin{array}{l}13.2 \\
23.9\end{array}$ & $\begin{array}{l}1.4 \\
1.4\end{array}$ & $\begin{array}{l}95.3 \\
92.4\end{array}$ & $\begin{array}{l}0.9 \\
1.5\end{array}$ & $\begin{array}{l}3.8 \\
6.1\end{array}$ & $\begin{array}{l}3.8 \\
4.3\end{array}$ \\
\hline $\mathbf{S}$ & $\begin{array}{l}570 \\
600\end{array}$ & $\begin{array}{l}17.3 \\
33.5\end{array}$ & $\begin{array}{l}1.2 \\
0.9\end{array}$ & $\begin{array}{l}91.0 \\
70.8\end{array}$ & $\begin{array}{l}\text { 3. } 2 \\
4.2\end{array}$ & $\begin{array}{r}5.8 \\
25.0\end{array}$ & $\begin{array}{r}7.5 \\
11.0\end{array}$ \\
\hline S B F & $\begin{array}{l}570 \\
600\end{array}$ & $\begin{array}{l}43.7 \\
45.7\end{array}$ & $\begin{array}{l}0.7 \\
0.8\end{array}$ & $\begin{array}{l}90.1 \\
88.3\end{array}$ & $\begin{array}{l}1.4 \\
2.2\end{array}$ & $\begin{array}{l}8.5 \\
9.5\end{array}$ & $\begin{array}{l}3.7 \\
4.6\end{array}$ \\
\hline A B F & $\begin{array}{l}570 \\
600\end{array}$ & $\begin{array}{l}32.6 \\
49.1\end{array}$ & $\begin{array}{l}1.2 \\
1.1\end{array}$ & $\begin{array}{l}86.4 \\
82.6\end{array}$ & $\begin{array}{l}3.8 \\
2.0\end{array}$ & $\begin{array}{r}9.8 \\
15.4\end{array}$ & $\begin{array}{l}3.4 \\
4.1\end{array}$ \\
\hline OBF & $\begin{array}{l}570 \\
600\end{array}$ & $\begin{array}{l}40.3 \\
45.0\end{array}$ & $\begin{array}{l}0.9 \\
1.0\end{array}$ & $\begin{array}{l}89.0 \\
86.3\end{array}$ & $\begin{array}{l}2.7 \\
3.7\end{array}$ & $\begin{array}{r}8.3 \\
10.0\end{array}$ & $\begin{array}{l}2.7 \\
3.1\end{array}$ \\
\hline
\end{tabular}

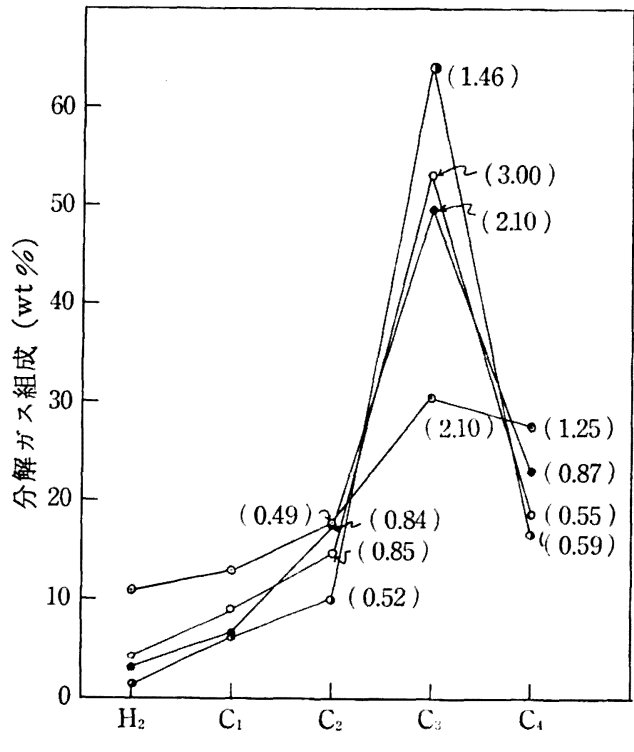

生成ガス

図 5 分解ガス組成分布（原料 $n$-ヘキサン）

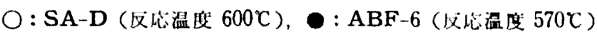
O: S ("600 C), O:SBF-6 (" 困中の数字は（オレフィン/パラフィン）の值を示す

因 5 は $n$-ヘキサンの 20 ３0\% 反応率水準で分解ガスの組成 を炭素数別にまとめたものであるが，S，SBF-6，SAD，ABF-6 はすべて $C_{3}$ にピークを有する分布で，その尖鋭度は SBF, SAD, $\mathrm{ABF}, \mathrm{S}$ の順になり, $\mathrm{S}$ は $\mathrm{C}_{3}$ が少なく $\mathrm{H}_{2}, \mathrm{C}_{1}, \mathrm{C}_{2}, \mathrm{C}_{4}$ が多い。 $\mathrm{SAD}$ はプロピレン，水素, コークス共に $\mathrm{ABF}-6$ 上りる多い。 これは接近した反応䜌水準を持つためには ABF，SBF よりも节 酷な条件が要求されるためである。 
$2 \cdot 4 \cdot 2$ で述べたような分析法で触媒中のホウ素およびフッ素の 含有量を求めたところ，ホウ素については分析值と計算値とよく 一致しているが，フッ素の分析值は計算值よりも常に 20〜25\% 低い值を示した。特にフッ素の量が多くなる程計算値と分析値の 差が大きい。

\section{4 触媒調製上の差異}

$2 \cdot 2$ で述べたようにホウフッ化水素酸を均質混合法および含浸 法によって調製した場合，得られた触媒の酸性度とパルス法によ るnーヘキサンの分解反応の結果を表 4 亿示す。

表 4 触媒調彆上の差異

\begin{tabular}{|c|c|c|c|c|}
\hline \multirow{3}{*}{ 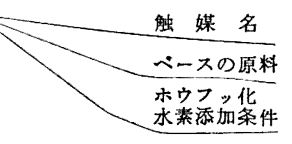 } & DABF-6 & ABF-6 & DOBF-6 & OBF-6 \\
\hline & \multicolumn{2}{|c|}{ 硝䤇アルミニウム } & \multicolumn{2}{|c|}{$\begin{array}{l}\text { プルミニウムイ } \\
\text { プロポオキシド }\end{array}$} \\
\hline & 含漫法 & 均質混合法 & 含浸法 & 均翼混合法 \\
\hline $\begin{array}{l}\text { 表 面 䆏 }\left(\mathrm{m}^{2} / \mathrm{g}\right) \\
\text { 酸性度 }(n \text { ーブルアミン滴定量 })\end{array}$ & 241 & 242 & 252 & 223 \\
\hline $\mathrm{p} K_{\mathrm{a}} \leqq+4.0$ & 0.38 & 0.56 & 0.38 & 0.44 \\
\hline+3.3 & 0.38 & 0.52 & 0.38 & 0.43 \\
\hline+1.5 & 0.36 & 0.50 & 0.37 & 0.42 \\
\hline-3.0 & 0.32 & 0.50 & 0.33 & 0.42 \\
\hline-5.6 & 0.26 & 0.37 & 0.17 & 0.17 \\
\hline-8.0 & 0.18 & 0.32 & - & 0.12 \\
\hline 反応事 $\mathrm{wt} \%$ 対原料 & 9.5 & 21.1 & 20.3 & 36.8 \\
\hline
\end{tabular}

同一原料を用いた場合，均質混合法で調製した触媒は，含浸法 に比して酸性度は大きいが，乙かし表面積では著しい差がないの で, 表面積当りの酸性度が大きくなり, したがって均質混合法で 調製した触媒の活性が高い原因であると考えられる。

\section{5 軽咓炭化水素の分解}

工業的見地から原料として表 5 に示されるような軽ナフサおよ び改質ガソリンから芳香族分を除いたラフィネートオイルを用 い，触媒には市販シリカ・アルミナ SAD および ABF-6 を用い て行なった結果を表 6 に示す。

ABF-6 触媒はシリカ・アルミナ触媒に比して表面積は約 2 分 の 1 であるが，非常に活性が高く，液状生成物中の芳香族分も多 い。図6に示されるよ5にラフィネートオイルを原料とした場合 に分解ガス中の成分の分布も大きな差異は認められなかった。全 体のオンフィンは ABF-6 の方が多く, 同一反応条件では市販の $\mathrm{SAD}$ に比較すると約 2 倍の収率でプロピレンとブチレンが得ら れた。反応開始後次第に炭素状堆積物が蓄積されるので, 活性が 低下してゆくが，その尺度としてガスの生成速度に注目すると， 反応が約 1 時間経過した後約 10〜20\%の低下が見られる。しか

$\begin{array}{ccc}\text { 表 } 5 & \begin{array}{c}\text { 原 } \\ \text { 料 } \begin{array}{c}\text { 油 } \\ \text { 軽ナフサ }\end{array}\end{array} \text { 状 } \\ \text { ラフィネート }\end{array}$

表 6 石油系炭化水素の接触分解

反応条件 L.H.S.V. $\fallingdotseq 1.7$ (油 $l /$ 触媒 $\cdot l / \mathrm{hr}$ ) 反沈温度 $570 \mathrm{C}$

\begin{tabular}{|c|c|c|c|c|}
\hline 触 & \multicolumn{3}{|c|}{ シリカ・アルミナ SAD } & $\mathrm{ABF}-6$ \\
\hline \multicolumn{5}{|l|}{ 酸性度 $(n$-ブチルアミン滴定量) } \\
\hline $\mathrm{p} K_{\mathrm{a}} \leqq 4.0$ & & 0.64 & & 0.56 \\
\hline 3.3 & & 0.63 & & 0.52 \\
\hline 1.5 & & 0.53 & & 0.50 \\
\hline-5.6 & & 0.44 & & 0.37 \\
\hline-8.2 & & 0.18 & & 0.32 \\
\hline 原 料 油 棰 & 軽ナフサ & ラフィネート & 軽ナフサ & ラフィネート \\
\hline \multicolumn{5}{|l|}{ 分解 結 果 } \\
\hline $\mathrm{H}_{2}(\mathrm{wt} \%)$ & 0.3 & 0.5 & 0.7 & 1.1 \\
\hline $\mathrm{CH}_{4}$ & 1.3 & 2.0 & 3.1 & 4.6 \\
\hline $\mathrm{C}_{2} \mathrm{H}_{4}$ & 1.3 & 3.4 & 4.3 & 6.9 \\
\hline $\mathrm{C}_{2} \mathrm{H}_{8}$ & 0.8 & 0.7 & 2.8 & 2.3 \\
\hline $\mathrm{C}_{3} \mathrm{H}_{8}$ & 5.9 & 9.4 & 7.7 & 16.2 \\
\hline $\mathrm{C}_{3} \mathrm{H}_{8}$ & 2.1 & 3. 3 & 3.5 & 5.2 \\
\hline $\mathrm{C}_{4} \mathrm{H}_{8}$ & 1.1 & 3.8 & 6.1 & 9.6 \\
\hline $\mathrm{C}_{4} \mathrm{H}_{10}$ & 1.4 & 5.7 & 4.3 & 5.7 \\
\hline ガ ス 収革 & 14.2 & 28.8 & 32.5 & 51.6 \\
\hline 波状生成物收率 & 84.3 & 65.3 & 62.5 & 42.0 \\
\hline " 組成 & & & & \\
\hline (パシフィン (vol\%) & 96.2 & 84.2 & 92.4 & 71.9 \\
\hline$\{$ オレフィン & 2.1 & 3.2 & 2.5 & 2.6 \\
\hline (劳香族 & 1.7 & 12.6 & 5.1 & 25.5 \\
\hline カーボン状物犋 & 1.1 & 4.0 & 1.3 & 7.1 \\
\hline
\end{tabular}

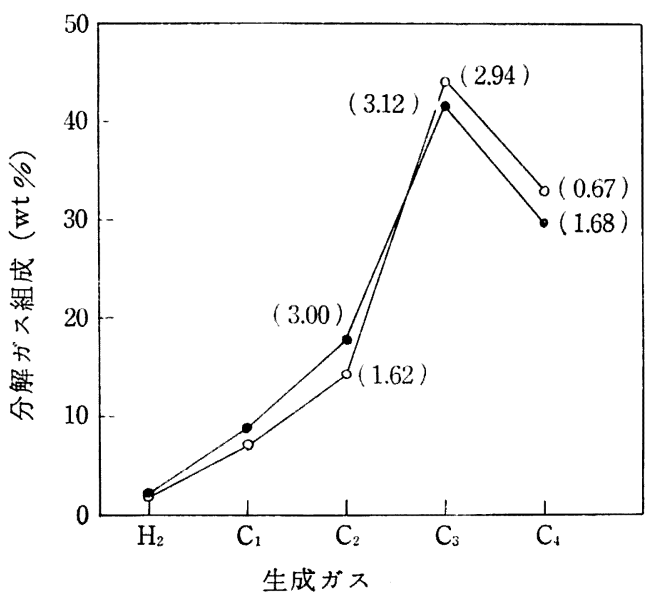

図6 分解ガス組成分布（原料ラフィネートオイル） $\mathrm{O}: \mathrm{SAD}-6$ (反応温度 $600 \mathrm{C}$ )

- : $\mathrm{ABF}-6$ ( " $570 \mathrm{C})$

因中の数字は（オレフィン/パラフィン）の値を示す

し，両者ともほとんど平衡活性に到達している。その場合でも ABF-6 触媒は SAD より約 2 倍のガス生成速度を有している。

平均分子量からみると軽ナフサは炭素数約 5 で, ラフィネート

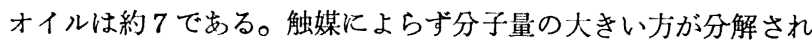
易い。ABF-6 でも SAD でもラフィネートオイルからプロピレ ン, ブチレンが，軽ナフサの場合より約 2 倍得られた。平均分子 量の小さい原料油を用いるときさ反佟件を苛酷にするか，触媒 の活性の高いものを適用しなければ产収率のプロピレン，ブチレ ンは得られない。

\section{$3 \cdot 6$ 酸性度之活性}

プロトン交換法 ${ }^{12)}$ で求めた酸性度とフッ化物の含有量に対する 関係は，図 7 に示すよ5に, フッ化物の含有量が增加するにした がって，プロトン酸が增加している。さらに Benesi9,10) の方法 によって求めた酸性度の分布を図 8 に示す。全酸量は余り変化は しないが，酸強度が $\mathrm{p} K_{\mathrm{a}}=-3.0$ 上り弱い酸の占める割合が減少 している。さらにフッ化物の含有量が多くなると，表面䅡が次第 


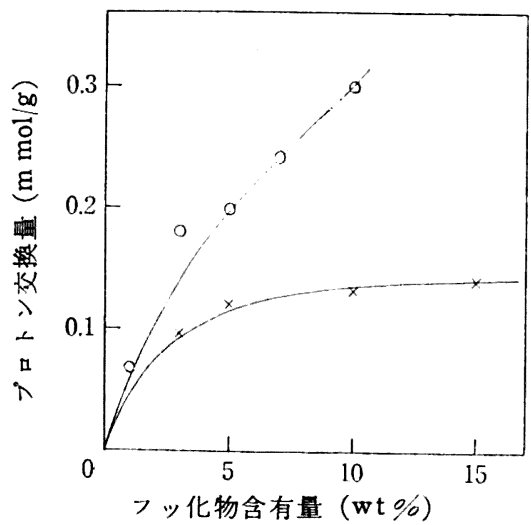

困 7 フッ化物含有量とブロトン交換

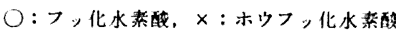

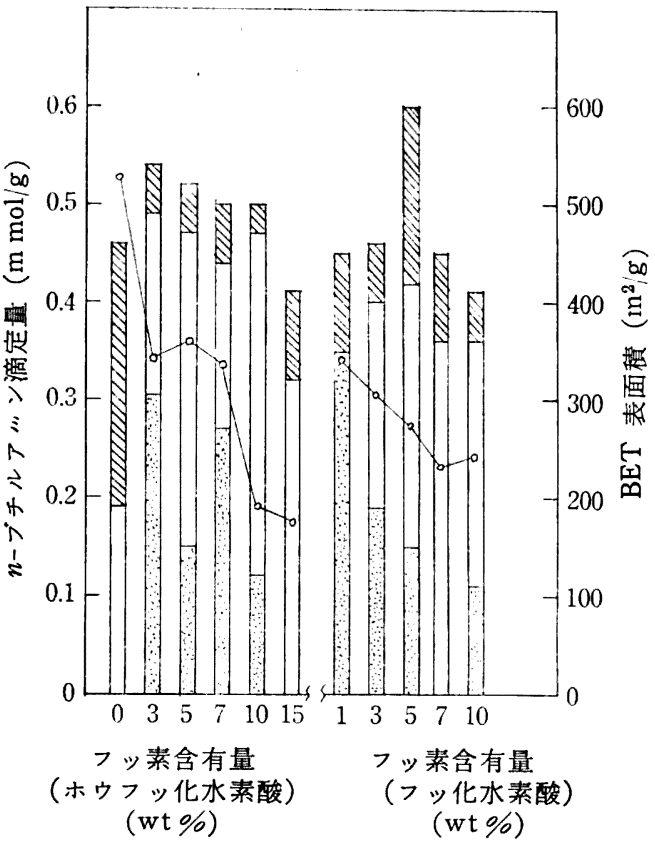

因 8 酸性度および表面積

斜線は-3.0 $\leq \mathrm{p} K_{\mathrm{a}} \leq+4.0$ 無地の部分は $-5.6 \leq \mathrm{p} K_{\mathrm{a}} \leq-3.0$ その下は $\mathrm{p} K_{\mathrm{a}} \leq-5.6$ を示す

に減少するので，触媒表面積当りの酸性度は増加している。この 事実は, アルミナに $\mathrm{Al}\left(\mathrm{BF}_{4}\right)_{3}$ を加えた場合 $\left.{ }^{14}\right)$ も認められてい る。軽質炭化水素の接触分解からプロピレンおよびブチレンを得 るためにある程度強いプロトン酸の存在と表面積当りの酸性度の 高いことが必要と考えられる。

\section{4 考察}

シリカ・アルミナ触媒について酸性度と炭化水素の接触反応に

14) V. Bosacek, R. Polak, E. Kucera, V. Danes, Collection Czech. Chem. Commun. 27, 2575 85 (1962).

15) O. Johnson, J. Phys. Chem. 59, 827 (1955).

16) M. W. Tamele, L. B. Rayland, L. D. Rampino, W. G. Schlaffer, Proc. Third World Pet. Congr. Meeting at Los Angels Sect. IV 98 Leiden (1951).
おける関係を明らかにしようとする試みが 現 在まで数多くあっ た。一部, 定量的結果を得ているものに, Johnson ${ }^{15)}$, Tamele ${ }^{16}$ の研究があり, Benesi の方法で測定された酸性度と炭化水素の 分解活性の関係について Hirschler ${ }^{17)}$ の研究がある。Hirschler はガソリン製造には多量の弱い酸を含む触媒が有利であり, 強い 酸を含む触媒はコークスの生成量が多いと述べている。炭化水素 の接触分解に対してルイス酸およびブレンステッド酸のいずれが 有効であるかという問題について統一された見解はない。

Webb ${ }^{18)}$ はアンモニアの吸着の測定から, フッ化水素酸処理に より, 酸性点の数は余り変化していないが, 酸の強度が強くなっ ていると報告している。一方，Holm はアンモニアの吸着熟の測 定からフッ化物の含有量が增加すると吸着熱が低下するために, 反応物の触媒表面上の易動性が大きくなると述べている。 Hirschler はトリフェニルメタノール誘導体を指示薬としてn-ブチル アミンの滴定によって強いブレンステッド酸の存在を確認し, 強 いブレンステッド酸は弱いルイス酸よりもアンモニアの吸着に刘 して弱いこともあり得る，という仮定もできるのではないかと述 べている。この点について, 斯波ら ${ }^{19}$ のシリカ・アルミナに関す る報告の中で, アンモニアの吸着とブレンステッド酸の関係と合 わせて考皇ると興味深いものがある。

ッフ化物がアルミナ触媒に添加されると, 触媒表面上にブレン ステッド酸が生成すると考えられるが，その機構について Rijnders $\left.{ }^{2}\right)$ はアルミナの - $\mathrm{OH}$ 基が電気陰性度のさらに高い $\mathrm{F}^{-}$ によって置換されてシリカ・アルミナのような性質を示し，アル ミナの持つ脱水素能を減少させると述べている。

この他に，水溶液中で処理をするもので，アルミナを塩化ナト リウム水溶液中で処理した場合に, Haag ら 20)によって示される ような機構（I）と同様な機構（II）によって,ブレンステッド 酸が形成されるものと考えられる。

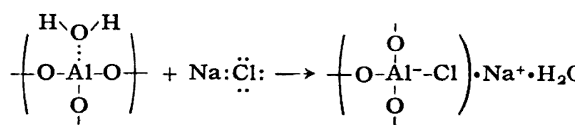

$$
\begin{aligned}
& \left(\begin{array}{c}
\mathrm{H}_{\backslash} \mathrm{O}^{\prime \mathrm{H}} \\
\vdots \\
\mathrm{O}-\underset{1}{\mathrm{~A}}-\mathrm{O} \\
\mathrm{O}
\end{array} \mid+\mathrm{H}: \ddot{\mathrm{F}}: \longrightarrow\left(\begin{array}{c}
\mathrm{O}^{\prime} \\
\mathrm{O}-\mathrm{Al}^{\prime}-\mathrm{F} \\
\dot{\mathrm{O}}
\end{array}\right) \cdot \mathrm{H}^{+} \cdot \mathrm{H}_{2} \mathrm{O}\right.
\end{aligned}
$$

ホウフッ化水素酸によるアルミナの活性化は, その加水分解 ${ }^{21}$, 22)によって得られるフッ化水素酸による寄与が大きいものと考兄 られる。

$$
\begin{aligned}
& \mathrm{HBF}_{4}+\mathrm{H}_{2} \mathrm{O} \rightleftharpoons \mathrm{HBF}_{3}(\mathrm{OH})+\mathrm{HF} \\
& \mathrm{HBF}_{3}(\mathrm{OH})+\mathrm{H}_{2} \mathrm{O} \rightleftharpoons \mathrm{HBF}_{2}(\mathrm{OH})_{2}+\mathrm{HF}
\end{aligned}
$$

終りに, 本研究を行なうについて, 終始御助言を賜わりました, 丸善石油株式会社, 上妻常英氏括よび沿沢芳雄氏，丸善石油化学 株式会社，金崎健児氏に深甚の謝意を表します。

17) A. E. Hirschler, A. Schneider, J. Chem. Eng. Data. 6. 313 (1961).

18) A. N. Webb, Ind. Eng. Chem. 49, 261 (1957).

19）斯波，青沼，佐藤，触媒 5, No. 3, 274 (1963).

20) H. Pine, W. O. Haag, J. Am. Chem. Soc. 82, 2471 (1960).

21) C. A. Wamser, J. Am. Chem. Soc. 70, 1219 (1948).

22) C. A. Wamser, ibid. 73, 409 (1951). 